\title{
Load-Bearing Characteristics of Large-Diameter Rock-Socketed Piles Based on Ultimate Load Tests
}

\author{
Xueying Liu $\mathbb{D}^{1},{ }^{1}$ Xiaoyu Bai $\left(\mathbb{D},{ }^{1,2}\right.$ Mingyi Zhang, ${ }^{1,2}$ Yonghong Wang, ${ }^{1,2}$ Songkui Sang, \\ and Nan Yan $\mathbb{D}^{1,2}$ \\ ${ }^{1}$ School of Civil Engineering, Qingdao University of Technology, Qingdao 266033, China \\ ${ }^{2}$ Cooperative Innovation Center of Engineering Construction and Safety in Shandong Blue Economic Zone, \\ Qingdao University of Technology, Qingdao 266033, China
}

Correspondence should be addressed to Xiaoyu Bai; baixiaoyu538@163.com

Received 4 March 2020; Accepted 2 July 2020; Published 26 July 2020

Academic Editor: Luís Evangelista

Copyright (c) 2020 Xueying Liu et al. This is an open access article distributed under the Creative Commons Attribution License, which permits unrestricted use, distribution, and reproduction in any medium, provided the original work is properly cited.

As part of a large converter project in Shandong Province, vertical static load tests and internal force tests were conducted on three large-diameter rock-socketed piles, their load transfer mechanism was clarified, and the ultimate side resistance and ultimate resistance performance characteristics of the rock-socketed sections were analyzed. The test results showed that the three test piles were damaged under maximum loading, the $Q-s$ curve exhibited a steep drop, the pile compression was around 1.2 times the pile diameter, and the bearing capacity of a single pile did not meet the design requirements. The side and end resistances of the three test piles all reached their ultimate values, but the ultimate side resistance was lower than the lower limit of the recommended value in the current technical code for building pile foundations. The end resistance under maximum loading accounted for $38.4-53.8 \%$ of the peak load, which was relatively high. By comparing it with other studies, there was no significant correlation between the coefficient of rock ultimate side resistance of the rock-socketed segment and the pile diameter of the rock-socketed segment. However, the coefficient of ultimate resistance increased gradually with the pile diameter. However, the latter correlation was not significant when the pile diameter was less than $1000 \mathrm{~mm}$.

\section{Introduction}

Rock-socketed piles (RSPs) are used widely in civil engineering because of their advantages of high bearing capacity, small settlement deformation, rapid convergence, and strong geological adaptability. As the loads on construction foundations have increased, so the analysis of bearing capacity and static load tests of RSPs have shifted gradually toward large-diameter and deep RSPs. However, studying the bearing characteristics of RSPs comprehensively is limited by the following facts: (i) field tests of RSPs are expensive, (ii) destructive tests are difficult to complete, and (iii) complete and effective sets of static test data from the field are scarce.

Currently, the relevant research carried out by scholars both in China and internationally is mainly regarding bearing properties and load transfer. Pells and Turner [1] studied the load transfer of large-diameter pelitic soft rock inlaid RSPs in the Nanjing area and found that the load transfer behavior is related closely to the construction technology, construction quality, and load level. Zhang et al. [2] discussed the bearing characteristics and failure modes of RSPs based on field pile tests and laboratory model tests. From field tests, Ismael et al. [3] obtained the uplift capacity of piles bored in dense calcareous soil at three sites in Kuwait; they compared the test results with empirical correlations relating the skin friction to the standard penetration test results and analyzing the test data indicated substantial load transfer similar to that in clean silica sand, with no reduction for the presence of carbonates with this method of construction. Based on the dilatation and failure mechanism of pile-rock interface, Zhao et al. [4] established a side friction transfer model suitable for weak rock and rock-embedded piles and obtained analytical expressions for 
the side friction and axial force of a pile under failure and elastic conditions. Leung et al. [5] summarized 20 years of developments on RSPs both in China and internationally; they analyzed 150 sets of field test results and two sets of long-term in situ observations, and they found some general relationships between (i) the ratio of base resistance to pile capacity of an RSP under vertical load and (ii) its length-todiameter ratio. Ho et al. [6] installed an instrumented bored pile and performed loading tests to clarify the mechanism of base grouting and determine its effectiveness; from straingauge data, they determined the load transfer characteristics and mobilization curves for skin friction resistance and endbearing resistance. Donald et al. [7] used theoretical analyses of pile socket behavior to illustrate the effects of various assumptions that are made frequently in socket design, the most important one regarding the nature of pore water drainage during loading, with $\mathrm{phi}=0$ behavior differing significantly from c-phi or c-phi joint behavior. Xing et al. [8] found that pile shaft resistance develops before pile tip resistance, with the shaft load share decreasing as the tip load share increases with increasing load. They also confirmed the reliability of distributed optical-fiber technology for determining the load-bearing characteristics of large-diameter bored RSPs in complex geological conditions; they verified the feasibility of optical-fiber technology through indoor model tests and then studied the bearing characteristics and load transfer mechanism of large-diameter RSPs systematically through data collection, collation, and analysis during site burial and construction. Tosini et al. [9] discussed two load tests of finite element interpretation carried out on bentonite slurry piles bored in granular soil, from which they drew some conclusions about the possible causes of the observed inconsistency and how the construction technology influenced the interaction between the pile tip and the soil underneath it. Chen et al. [10] discussed the load transfer mechanism and vertical bearing characteristics of RSPs in deep backfill, analyzed the impact of dynamic compaction pretreatment technology on the bearing capacity of deep backfill, summarized the existing methods for estimating the ultimate side friction resistance of the rock-socketed section, and evaluated its applicability under site conditions. Lu et al. $[11,12]$ collected test results regarding the vertical bearing capacity of RSPs under different rock-socketed conditions and analyzed the distribution of the ultimate resistance of the RSPs and the ultimate side resistance of the rocksocketed segments.

The bearing capacity of an RSP is calculated mainly using empirical and semiempirical formulas with many empirical parameters, and the method for determining the comprehensive coefficients of side resistance and end resistance has some limitations. To date, there have been few comprehensive studies of the side and end resistances of an RSP, so we must carry out effective analysis on calculating the ultimate bearing capacity of an RSP. Therefore, this article relies on a large converter project in Shandong Province; through the static load test and pile stress test of three largediameter bored piles, the ultimate lateral and ultimate resistances of rock-socketed piles are analyzed in detail. Compared with other experimental results, the influence factors of rock ultimate side resistance coefficient and ultimate end resistance coefficient in rock-socketed segment are discussed. The present experimental results could serve as reference for future theoretical research on and engineering applications of RSPs.

\section{Test Overview}

2.1. Project Overview. The test site of this project is located in the Xujiazhuang area of Jinan, the main project being a large converter project. In this field, there are six bored piles with large-diameter and deep-socketed rock. The bearing strata are all limestone ones, and the socketed rock is around $1.0 \mathrm{~m}$ deep. The specific parameters of the three test piles selected in this paper are given in Table 1.

2.2. Geological Survey of Site. The terrain of the field is flat, and the soil is evenly distributed. From top to bottom, it is divided into four layers: the first two being mixed Earth and silty clay and the second two being limestone. The physical and mechanical parameters of each soil layer are given in Table 2.

According to the engineering investigation report, the silty clay layer in this field is relatively thick and contains some fine and coarse mixed soils. The core of mediumweathered limestone is relatively hard and complete, with a rock quality designation (RQD) of 60-90, and has relatively uniform distribution and stable mechanical properties, making it an ideal pile foundation bearing layer. Because of the large thickness of the rock strata, the drilling exposed the thickness of $0.20-6.00 \mathrm{~m}$ without exposing the bottom plate. Therefore, the foundation below the moderately weathered limestone strata can be regarded as a homogeneous foundation.

2.3. Test Scheme. Three test piles at different positions in the field were selected for the study. Before the tests began, the test piles were tested with low strain to ensure the integrity of the pile body, and those results showed that each test pile was a class-I pile with a complete pile body. In the main tests, each pile was subjected simultaneously to a vertical static load test and a stress test of the pile body to obtain the ultimate side and end resistances, and the distribution of side resistance of RSP and the performance characteristics of the end resistance were studied.

In the static load test, an anchor pile beam reaction device was used for loading, with the anchor pile providing the reaction force. Four QW320 hydraulic jacks were used to apply pressure, and the loading load was measured by a hydraulic gauge parallel to the jacks. The settlement of the pile top was measured automatically by four displacement sensors mounted symmetrically on the surface of the pile bearing plate.

The test loading method was the slow speed maintenance load method, and Table 3 gives the loading series and the initial and maximum loads on each test pile. Stage unloading was carried out after the test, with the unloading amount of each stage being twice the loading amount of each stage. 
TABle 1: Parameters of test piles.

\begin{tabular}{lcccc}
\hline Test pile & Length $(\mathrm{m})$ & Diameter $(\mathrm{mm})$ & Concrete strength & $\begin{array}{c}\text { Estimated ultimate bearing capacity of } \\
\text { single pile }(\mathrm{kN})\end{array}$ \\
\hline TP1 & 25.8 & 800 & C25 & 8349 \\
TP2 & 25.6 & 800 & C25 & C25 \\
TP3 & 25.5 & 800 & C & \\
\hline
\end{tabular}

TABLE 2: Geophysical and mechanical parameters of soil layers.

\begin{tabular}{|c|c|c|c|c|c|c|}
\hline Layer number & Soil type & $\begin{array}{c}\text { Soil } \\
\text { thickness (m) }\end{array}$ & $\begin{array}{l}\text { Compression } \\
\text { modulus (MPa) }\end{array}$ & $\begin{array}{l}\text { Internal } \\
\text { friction angle }\left({ }^{\circ}\right)\end{array}$ & $\begin{array}{l}\text { Cohesion } \\
(\mathrm{kPa})\end{array}$ & $\begin{array}{c}\text { Characteristic } \\
\text { value of } \\
\text { bearing capacity }(\mathrm{kPa})\end{array}$ \\
\hline (1) & Miscellaneous fill & $0.6 \sim 7.5$ & - & 9.0 & - & 65 \\
\hline (2) & Silty clay & $2.7 \sim 19.5$ & 7.0 & 14.5 & 34.0 & 190 \\
\hline (3) & Strongly weathered limestone & $0.7 \sim 7.8$ & 21.0 & 45.0 & - & 700 \\
\hline (4) & Moderately weathered limestone & Not through & 37.0 & 54.0 & - & 2100 \\
\hline
\end{tabular}

TABLE 3: Loading parameters of the static load test.

\begin{tabular}{lcccc}
\hline Test pile & Maximum load $(\mathrm{kN})$ & Loading series & Load per level $(\mathrm{kN})$ & Initial load $(\mathrm{kN})$ \\
\hline TP1 & 7792 & 14 & 557 & 1113 \\
TP2 & 8349 & 15 & 557 & 1113 \\
TP3 & 8349 & 15 & 557 & 1113 \\
\hline
\end{tabular}

During the test, both loading and reloading were completed automatically, and the test reading time and termination conditions were implemented in accordance with the technical code for construction foundation pile detection (JGJ 106-2014) [12]. The field test is shown in Figure 1.

To study in depth the distribution of side resistance and the characteristics of the end resistance of an RSP, it is necessary to measure the pile side and end resistances accurately. To do so, a vibrating string-type reinforcing bar meter was welded at the symmetrical position of main reinforcement in each test pile, and two reinforcing bar meters were installed at each boundary between adjacent soil layers. Test piles TP1-TP3 had five test sections from the first section to the pile end; the first measured section was the calibration section and was located on the buried surface of the pile body. Two steel bar meters were installed symmetrically for each section. Each test pile had a total of 10 bars, the layout of which is shown schematically in Figure 2. In order to avoid damage to the reinforcementmeter data lines during the construction process, it was first led to the ground along the main bar of the reinforcement cage, and then, a nylon bag was added at the top exit to protect it. Before each test, all the bars were measured to ensure that they had survived.

\section{Vertical Static Load Test of Single Pile}

A static load test is the most basic and reliable method for determining the bearing capacity of a single pile. A pile foundation is designed and constructed based mainly on the Q-s curve and ultimate bearing capacity of a pile. It is also a comprehensive reflection of the interaction of piles and soil. The $Q-s$ curve can be drawn from a static load test, and to study the $Q-s$ curve is also to study the vertical bearing

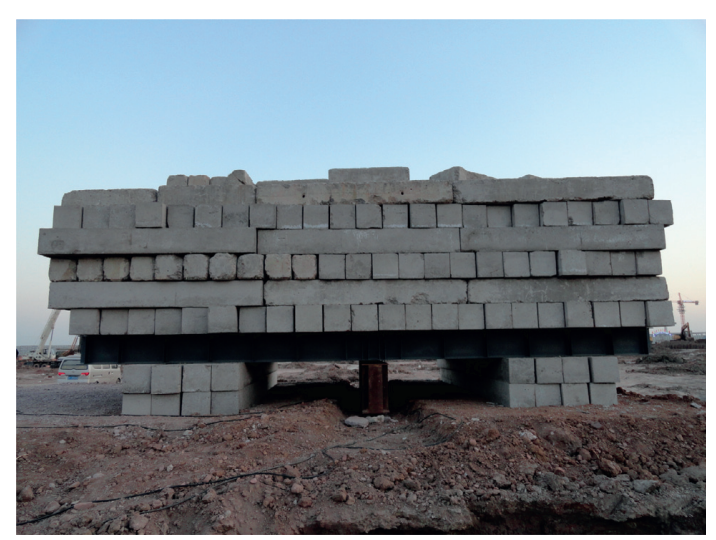

FIgURE 1: Static load test.

characteristics of a pile. The Q-s curves of the three present test piles are shown in Figure 3, and the total settlement of the pile top and the compression amount of the pile body of each test pile are given in Table 4 .

From Figure 3, the Q-s curve of each test pile was relatively gentle in the early stage, showing a slow descent. However, when the 13th loading stage was applied to TP1 and the 14th loading stage was applied to TP2 and TP3, the $Q-s$ curve dropped steeply and the settlement rate increased suddenly. The maximum settlement of the pile top was between $42.90 \mathrm{~mm}$ and $46.85 \mathrm{~mm}$, exceeding $40 \mathrm{~mm}$ and thus reaching the failure state [13]. According to the settlement amount, the load value corresponding to $s=40 \mathrm{~mm}$ can be obtained for the $Q-s$ curve with slow variation. For large-diameter piles, the load value corresponding to $s=0.03 \sim 0.06 D$ ( $D$ is the diameter of pile end) can be taken. From the static load tests, the characteristic vertical bearing 


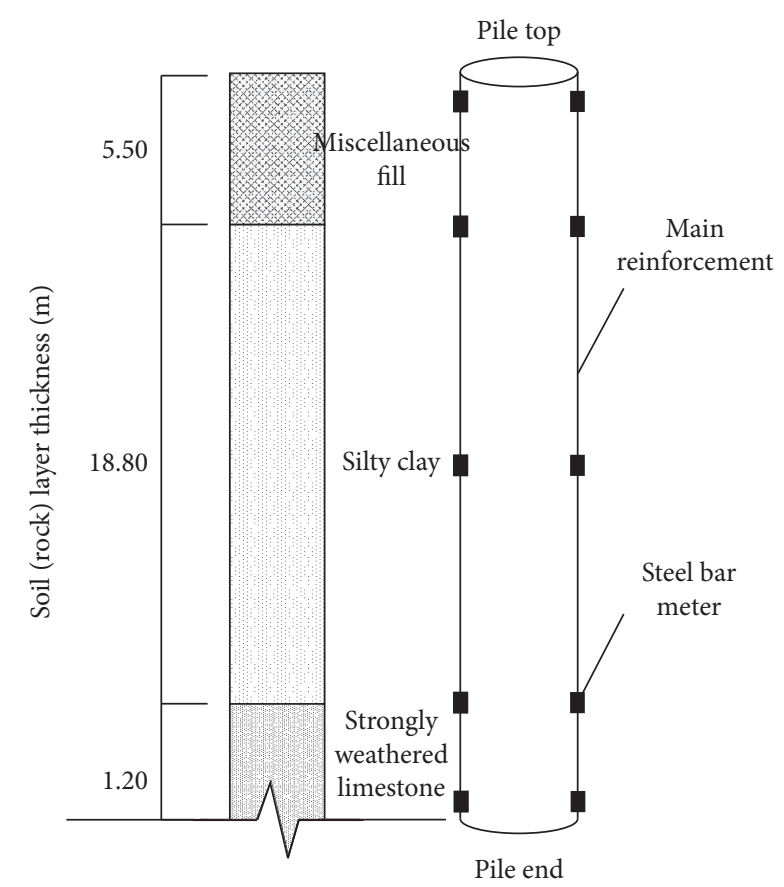

FIgURE 2: Cross section showing reinforcement meters on test pile.

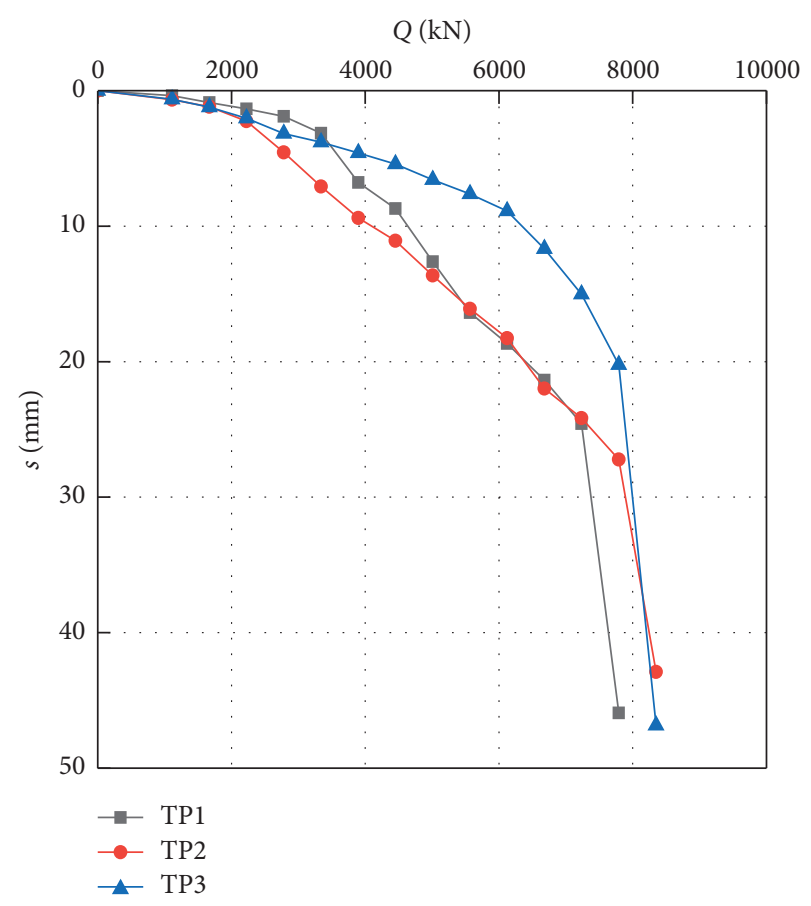

FIgURE 3: Q-s curves of test piles TP1-TP3.

capacity of a single pile was $3803 \mathrm{kN}$. According to the specification [13], the vertical bearing capacity of TP1 was $7235 \mathrm{kN}$ and that of TP2 and TP3 was $7792 \mathrm{kN}$, so none of the three test piles met the design requirements. During the static load tests, the three test piles exhibited failure characteristics under the action of the larger pile top load mainly because the bearing layers of the selected test piles were all strongly weathered limestone. According to the survey report, the main composition of this layer is calcite, generally mixed with yellow argillaceous limestone, which is soft in texture, and the dissolved pores and cracks in this layer are relatively developed, with a local honeycomb shape. Under the action of a large load, the pile end may enter into the hole from dissolution, resulting in the sudden increase of pile end settlement and the reduction of bearing capacity.

\section{Distribution of Axial Force on Pile Body}

It is assumed that that the steel bars and the concrete deformed consistently under load. Combined with the calibration coefficients of the steel bar meters and the elastic modulus of the pile body, the axial force at each section of the pile body can be calculated from the readings of the steel bar meters [14]. The axial force distribution of each section of each test pile is shown in Figure 4.

For each specific loading series, the axial force decreases gradually along the pile under test, and the distribution slope decreases with depth gradually. The axial force decreases fastest in the bedrock layer, reflecting the characteristic that the side resistance of the pile develops gradually from top to bottom along the pile body. This is mainly because the pressure acting on the pile body produces a compression deformation of pile body, and the relative displacement between the pile and the soil produces the pile side resistance that transfers the axial force to the soil around the pile, thereby causing the axial force to decrease gradually along the pile body. The difference in axial force between adjacent sections is the average side resistance of the soil (rock) layer. The lower the slope of the axial force curve, the greater the side resistance. In the strongly weathered limestone strata, the axial force slope of each test pile is the lowest, and thus, the side resistance is the greatest. Under the maximum load of the pile top, the pile top resistances of test piles TP1-TP3 were $3890 \mathrm{kN}, 3440 \mathrm{kN}$, and $2990 \mathrm{kN}$, respectively, accounting for $53.8 \%, 43.6 \%$, and $38.4 \%$, respectively, of the ultimate load mainly because the RSP side resistance first reached the ultimate state, and excess load is borne by the end resistance, and pile end resistance is at the ultimate state. In these static load tests, the three test piles reached the bearing limit state, so in its final state, it is both ultimate side resistance and ultimate end resistance.

\section{Distribution of Pile Side Resistance and Coefficient of Ultimate Rock-Induced Side Resistance}

5.1. Distribution of Pile Side Resistance. The pile side resistance is divided into that due to the overlying soil layer and that due to the rock-socketed segment. In the static load tests, according to the specification [13], the unit side resistance of the soil layer between two measured sections can be obtained from (i) the difference in the axial force between two adjacent detected sections and (ii) the geometric parameters of the pile. The calculation gives the unit side resistance of each test pile under various loading levels, and Figure 5 shows how that resistance varies with depth. 
TABLE 4: Results of static load test on each test pile.

\begin{tabular}{lcccc}
\hline Test pile & Maximum load $(\mathrm{kN})$ & Settlement of pile top $(\mathrm{mm})$ & Pile compression $(\mathrm{mm})$ & Pile end settlement $(\mathrm{mm})$ \\
\hline TP1 & 7792 & 45.93 & 9.29 & 36.64 \\
TP2 & 8349 & 42.90 & 9.88 & 33.02 \\
TP3 & 8349 & 46.85 & 9.84 & 37.01 \\
\hline
\end{tabular}
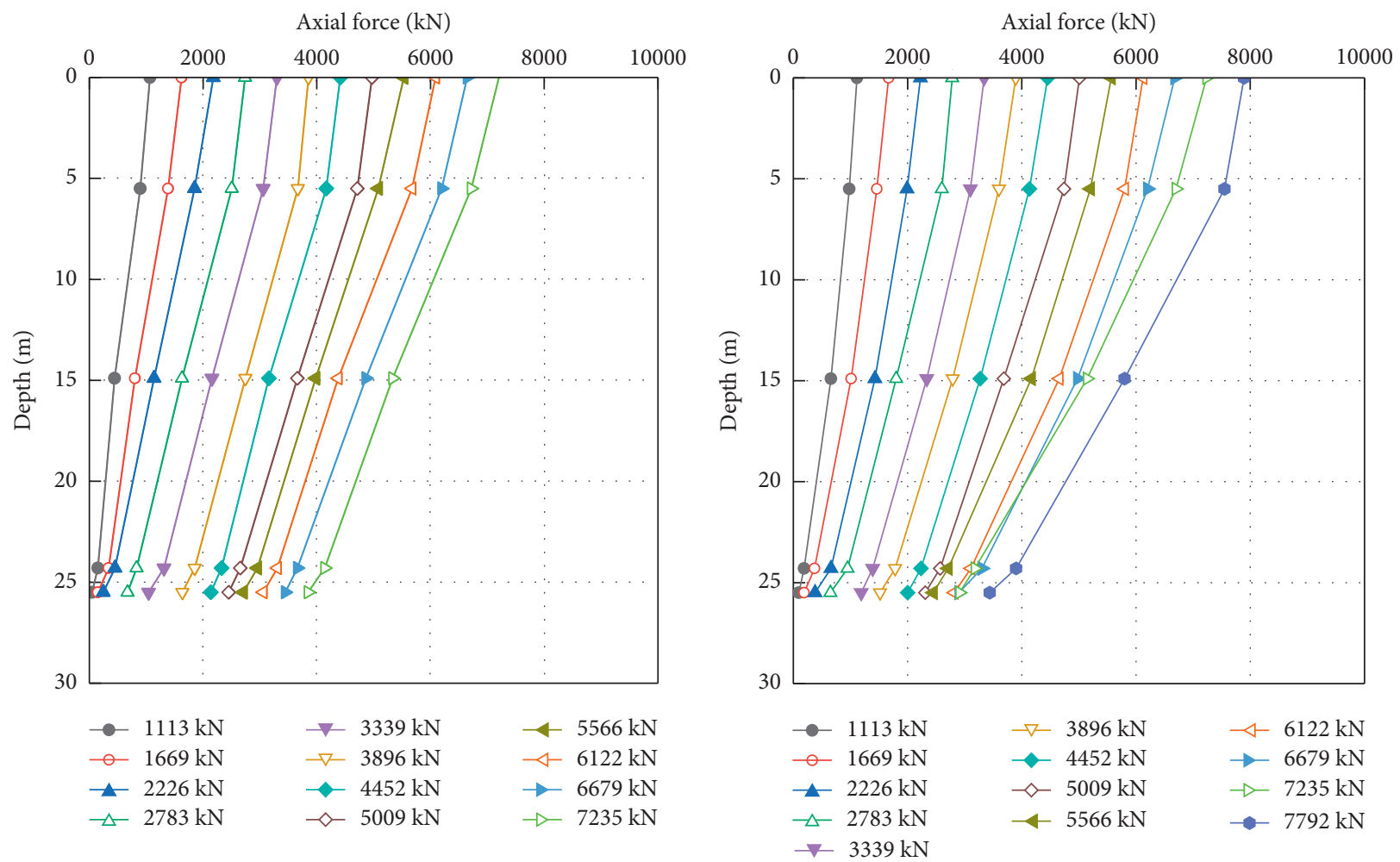

(a)

(b)

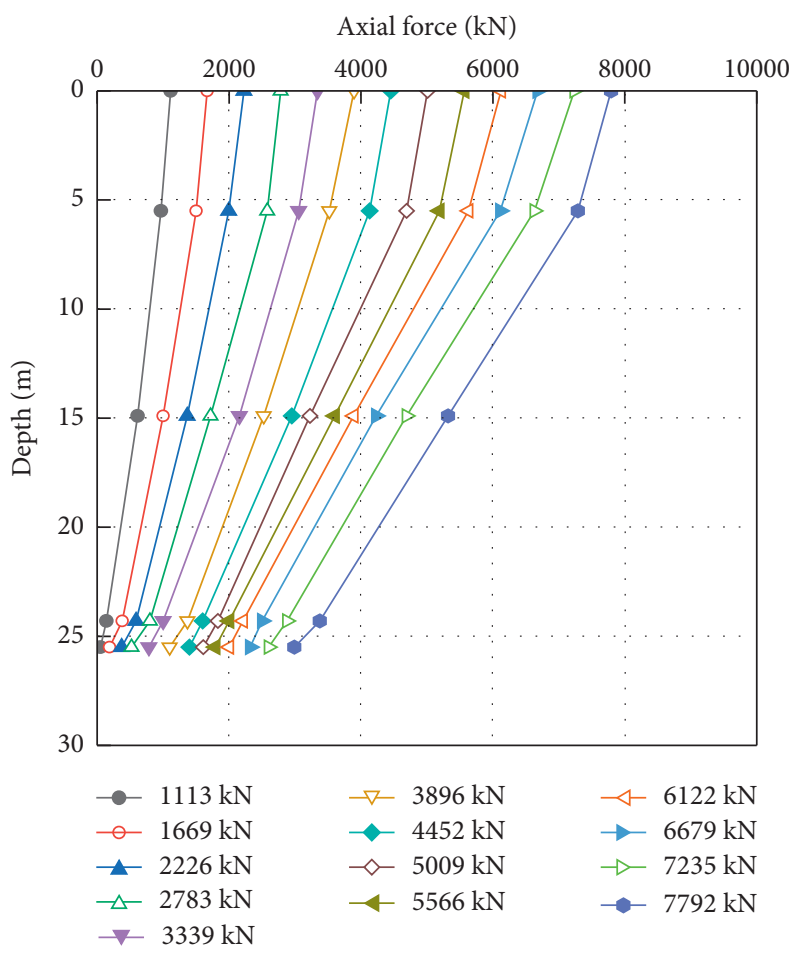

(c)

Figure 4: Axial force distribution of (a) TP1, (b) TP2, and (c) TP3. 

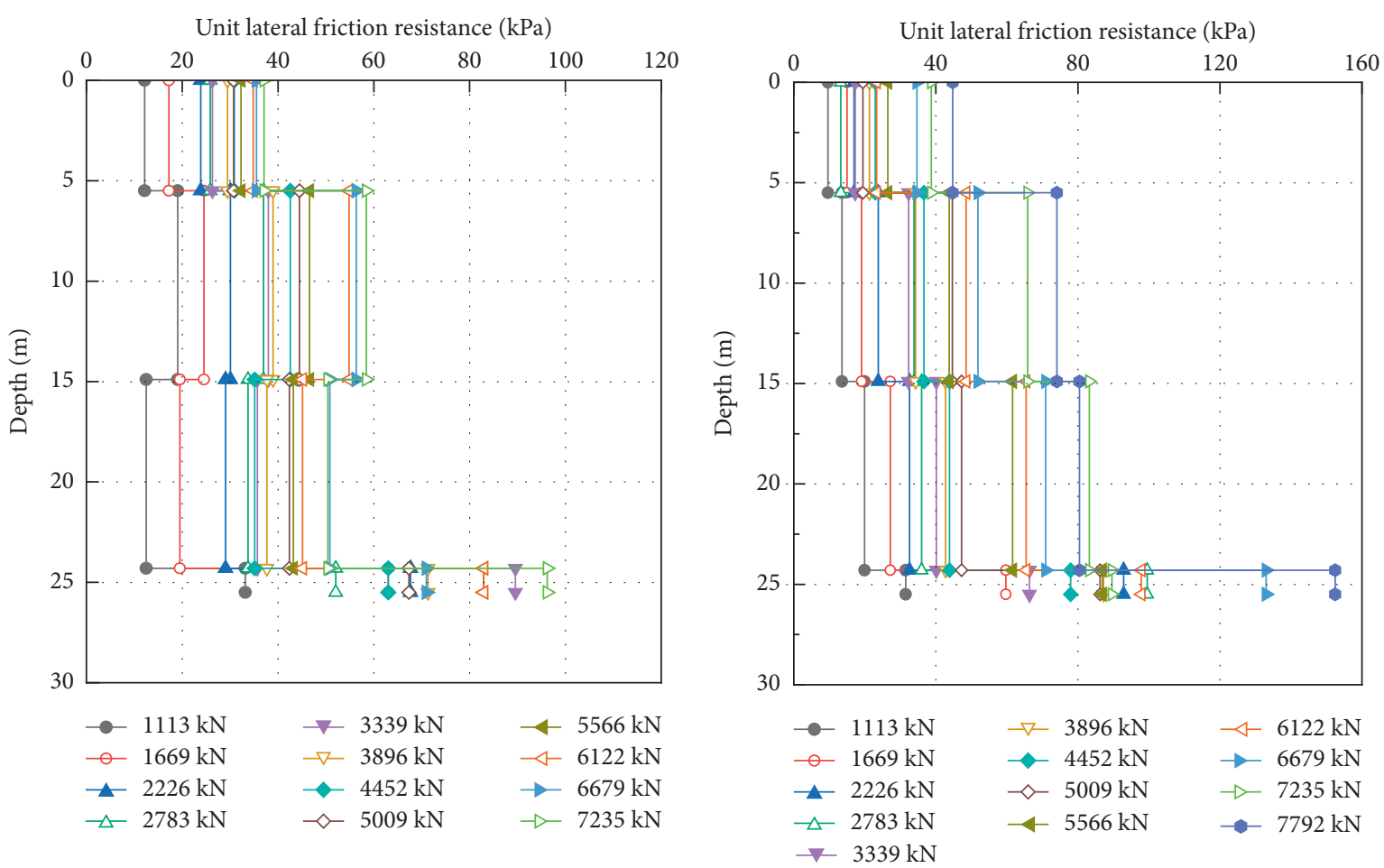

(a)

(b)

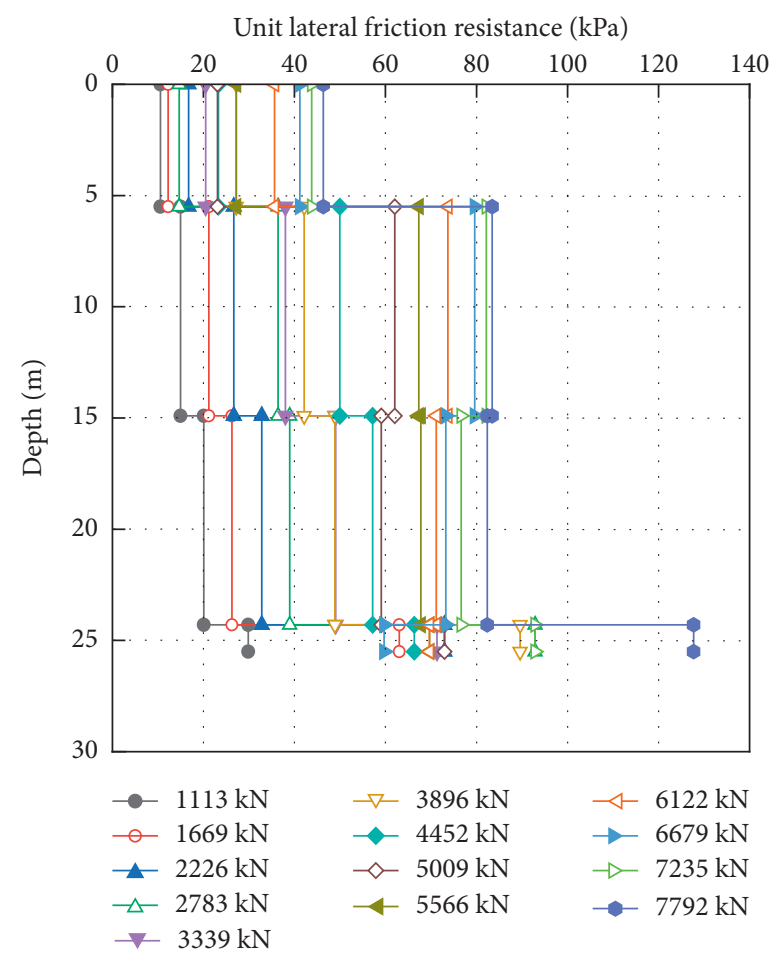

(c)

Figure 5: Distribution of side friction resistance: (a) TP1; (b) TP2; (c) TP3.

During the loading process, the unit side resistance of each test pile was distributed relatively consistently with depth along the pile. In the initial loading stage, both the pile top load and the side resistance of the rock layer were small, and the bearing capacity was provided mainly by the side resistance due to the upper soil layer. As the load was increased, the side resistance due to the rock increased gradually to bear the main part of the load, thus showing that the side resistance of a pile is nonsynchronous. Under the ultimate load, the side resistances due to the rock and soil 
reached their ultimate states, with the end resistance becoming the majority of the bearing capacity, which shows the characteristics of end-bearing pile.

The ultimate side resistance is the rock-soil resistance generated on the side surface of the pile body when the pile top bears the ultimate load. According to the specifications [13], the side resistance corresponding to a pile top settlement of $40 \mathrm{~mm}$ is generally defined as the ultimate side resistance. It can be seen that, under the action of the maximum load on the pile top, all three test piles were damaged and the side resistance reached the limit state. Therefore, the previous load was taken as the ultimate load. Table 5 compares (i) the measured values of the side resistance of each soil layer around the pile under the ultimate load with (ii) the recommended values of the specification.

In Table 5, there is consistency among the side resistances of the three test piles in a given soil layer, which shows that the test data are relatively reliable. Under the action of the ultimate load on the pile top, the average values of the ultimate side resistance in the miscellaneous fill and silty clay were higher than the specification recommendations mainly because the test piles passed through the soil layer and caused hole collapse, which leads eventually to diameter expansion $[15,16]$. The average ultimate side resistance in the strongly weathered limestone was lower than the specification recommendation mainly because of the multiple calcites in the limestone rocks, and part of skarn is petrolized and mixed with yellow argillaceous limestone. The soft texture of this layer developed fractures, and fractured rock mass leads to the limit value of lateral resistance provided by this rock layer being lower than the standard value.

5.2. Coefficient of Rock-Induced Ultimate Side Resistance and Influencing Factors. Here is an explanation of the definition of $\xi_{s} . \xi_{s}=q_{s} / \sigma_{c}$ in which RSP ultimate side resistance $q_{s}$ and rock uniaxial compressive strength of the ratio $\sigma_{c}$ for RSP rock-socketed section ultimate side resistance coefficient factor $\xi_{s}$. Based on this, this paper analyses the influence law of rock mass properties of rock-socketed segment on pile ultimate side resistance and the coefficient of rock-induced ultimate side resistance in the rock-socketed segment. The values of the coefficient of rock-induced ultimate side resistance obtained in the present tests are compared with collected test data on the pile diameter of the rock-socketed segment, the rock natural uniaxial compressive strength, and the RSP ultimate resistance. The experimental data were obtained from four papers [17-20], the authors and publication dates of which are listed in Table 6. In total, 34 RSPs were tested for their vertical bearing capacity under downward pressure, and the rock-socketed conditions and limit side resistance tests of rock-socketed sections are given in Table 7 (group 0 contains the test results from the present study). From Table 7, in Figure 5, the curve of the coefficient of rock-induced ultimate side resistance in the rocksocketed segment changing with pile diameter is drawn.

It should be noted here that the experimental work cited in this paper was carried out by scholars in different periods and regions under different rock-socketed rock types and strengths and under different rock-socketed pile end rocksocketed conditions. The author's test method for rocksocketed pile ultimate side resistance and determination principle of ultimate bearing capacity are also different. In this paper, the results of the original literature are directly used in the analysis, and the research conclusions obtained by this method will be more general.

Figure 6 shows that the coefficient of rock-induced ultimate side resistance of the rock-socketed segment varies greatly with the pile diameter, with no obvious correlation between the two. When the pile diameter exceeds $150 \mathrm{~mm}$, it has a very limited effect on the ultimate side resistance of the rock-socketed segment, which is similar to the research results of Williams and Pells [21]. This is mainly because the pile side resistance of the rock-socketed segment is caused by the pile-rock relative displacement, while the pile-rock relative displacement required for the rock mass to reach the ultimate side resistance state is relatively small, and it is approximately $2 \mathrm{~mm}$ in intact limestone [22]. The relative displacement required for the ultimate side resistance between pile and rock is related mainly to the type of rock mass, so the correlation between the ultimate side resistance of rock with limestone in the socketed segment and the pile diameter is weak.

\section{Pile End Resistance and Coefficient of Ultimate End Resistance}

6.1. Relationship between Pile End Resistance and Pile Top Load. In the present tests, the measured section at the bottom was very close to the pile end, and the axial force calculated from the measured section is considered to approximate the resistance at the pile end. How the pile end resistance varied with the pile top load is shown in Figure 7.

During the loading process, as the pile top load is increased gradually, the pile end resistance also increases. At the beginning of loading, when the pile top load is less than $2000 \mathrm{kN}$, the pile end resistance of three test piles increases linearly, accounting for a small proportion of the pile top load, always less than $25 \%$. At this point, the bearing capacity is provided mainly by the pile side resistance. As the pile top load is increased, the growth rate of the pile end resistance increases gradually, and the pile end resistance enters the stage of nonlinear rapid growth, at which time the proportion of the pile top load increases gradually. Under the action of a higher load, the pile end resistance continues to increase, and the proportion of the pile top load continues to increase. Under the action of the maximum load, the pile end resistance of piles TP1-TP3 accounted for 53.8\%, 42.4\%, and 38.4\%, respectively, of the pile top load. This is because each test pile reached the failure state under the action of the maximum load, with the pile side and end resistances both reaching their limit states. This behavior is characteristic of an end-bearing pile.

6.2. Coefficient of Ultimate Resistance and Influencing Factors. At present, the RSP ultimate side resistance $q_{p}$ and rock uniaxial compressive strength of the ratio $\sigma_{c}$ are defined as 
TABLE 5: Comparison between measured side friction resistance of each soil layer and recommended values.

\begin{tabular}{lccccc}
\hline \multirow{2}{*}{ Soil type } & \multicolumn{3}{c}{ Measured value of side resistance } & & \\
& & $(\mathrm{kPa})$ & & Average $(\mathrm{kPa})$ & Specification recommendation $(\mathrm{kPa})$ \\
& $\mathrm{TP} 1$ & $\mathrm{TP2}$ & $\mathrm{TP3}$ & 32.06 & 22 \\
Miscellaneous fill & 35.10 & 24.75 & 36.33 & 71.99 & 65 \\
Silty clay & 58.44 & 74.11 & 83.43 & 71.08 & 65 \\
Silty clay & 50.40 & 80.46 & 82.37 & 125.46 & 160 \\
Strongly weathered limestone & 96.20 & 152.46 & 127.72 & \\
\hline
\end{tabular}

TABLE 6: Authors and years for references in the present study [17-20].

\begin{tabular}{lcr}
\hline Number & Author(s) & Year \\
\hline 1 & McVay et al. & 1992 \\
2 & Gunnink and Kiehne & 1998 \\
3 & Long & 2000 \\
4 & Castelli and Fan & 2002 \\
\hline
\end{tabular}

TABLE 7: Data from load tests of side-bearing capacities of piles socketed into rock.

\begin{tabular}{|c|c|c|c|c|}
\hline Group & $\begin{array}{c}\text { Diameter } d \\
(\mathrm{~mm})\end{array}$ & $\begin{array}{l}\text { Uniaxial compressive strength } \\
\text { of } \operatorname{rock} \sigma_{c}(\mathrm{MPa})\end{array}$ & $\begin{array}{l}\text { Ultimate side resistance of rock- } \\
\text { socketed section } q_{s}(\mathrm{MPa})\end{array}$ & $\begin{array}{l}\text { Coefficient of ultimate side resistance of } \\
\text { rock-socketed section } \xi_{\mathrm{s}}\end{array}$ \\
\hline 0.1 & 800 & 0.51 & 0.096 & 0.188 \\
\hline 0.2 & 800 & 0.51 & 0.152 & 0.298 \\
\hline 0.3 & 800 & 0.51 & 0.128 & 0.251 \\
\hline 1.1 & 760 & 1.72 & 0.480 & 0.279 \\
\hline 1.2 & 760 & 2.30 & 0.390 & 0.170 \\
\hline 1.3 & 760 & 6.71 & 1.200 & 0.179 \\
\hline 1.4 & 760 & 3.55 & 0.690 & 0.194 \\
\hline 1.5 & 760 & 4.41 & 0.710 & 0.161 \\
\hline 1.6 & 910 & 4.55 & 0.820 & 0.180 \\
\hline 2.1 & 1200 & 2.50 & 0.400 & 0.160 \\
\hline 3.1 & 457.2 & 43.6 & 2.343 & 0.054 \\
\hline 3.2 & 457.2 & 73.8 & 0.916 & 0.012 \\
\hline 3.3 & 457.2 & 64.7 & 2.278 & 0.035 \\
\hline 4.1 & 350 & 25.0 & 0.750 & 0.030 \\
\hline 4.2 & 350 & 54.0 & 1.500 & 0.028 \\
\hline 4.3 & 350 & 29.0 & 1.000 & 0.034 \\
\hline 4.4 & 350 & 54.0 & 1.880 & 0.035 \\
\hline 4.5 & 350 & 51.0 & 1.920 & 0.038 \\
\hline 4.6 & 350 & 50.0 & 1.455 & 0.029 \\
\hline 4.7 & 300 & 92.0 & 0.550 & 0.006 \\
\hline 4.8 & 325 & 51.0 & 0.765 & 0.015 \\
\hline 4.9 & 350 & 51.0 & 1.620 & 0.032 \\
\hline 4.10 & 350 & 51.0 & 1.270 & 0.025 \\
\hline 4.11 & 210 & 78.0 & 0.620 & 0.008 \\
\hline 4.12 & 190 & 84.0 & 0.420 & 0.005 \\
\hline 4.13 & 600 & 50.0 & 1.950 & 0.039 \\
\hline 4.14 & 600 & 51.0 & 1.670 & 0.033 \\
\hline 4.15 & 600 & 50.0 & 0.500 & 0.010 \\
\hline 4.16 & 800 & 52.0 & 0.470 & 0.009 \\
\hline 4.17 & 800 & 50.0 & 2.000 & 0.040 \\
\hline 4.18 & 600 & 50.0 & 1.300 & 0.026 \\
\hline 4.19 & 600 & 16.0 & 0.910 & 0.057 \\
\hline 4.20 & 600 & 16.0 & 0.975 & 0.061 \\
\hline 4.21 & 800 & 25.0 & 0.995 & 0.040 \\
\hline 4.22 & 800 & 25.0 & 0.995 & 0.040 \\
\hline 4.23 & 190 & 40.0 & 3.000 & 0.075 \\
\hline 4.24 & 170 & 75.0 & 1.500 & 0.020 \\
\hline
\end{tabular}




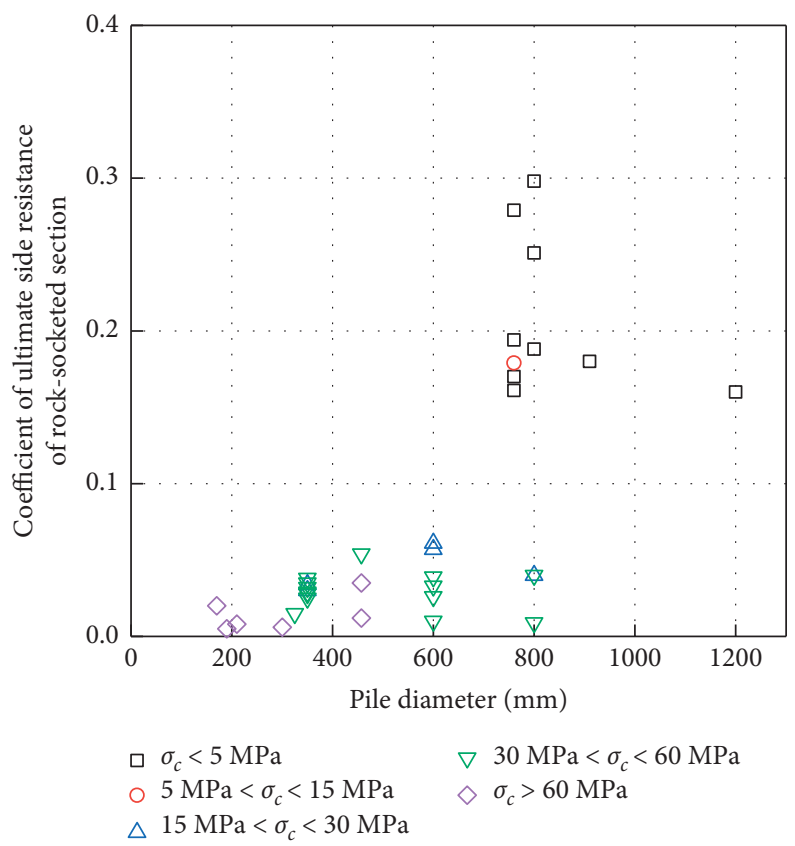

FIGURE 6: Relationship between pile diameter and coefficient of ultimate side resistance of rock-socketed section.

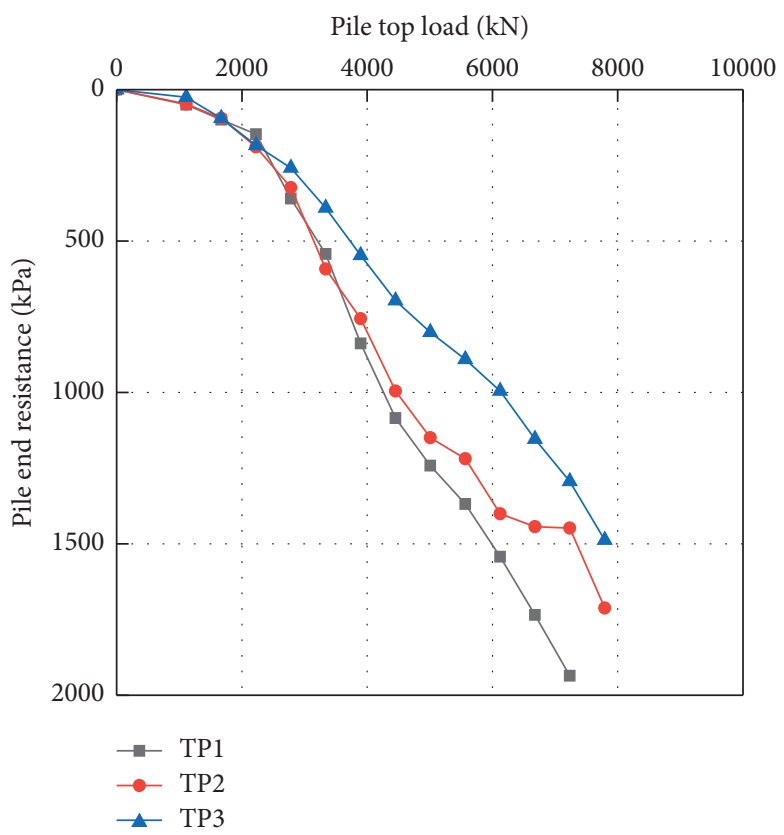

FIgURE 7: Relationship between pile top load and pile end resistance.

the coefficient of RSP ultimate resistance factor $\xi_{p}$, namely, $\xi_{p}=q_{p} / \sigma_{c}$. Based on this, the influence of rock strength on the ultimate resistance coefficient and ultimate end resistance coefficient of an RSP is analyzed. Based on this, the influence of rock strength on the ultimate resistance coefficient and ultimate end resistance coefficient of an RSP is analyzed and compared with collected test data on the pile diameter of the rock-socketed segment, the rock natural uniaxial compressive strength, and the RSP ultimate resistance. The test data were obtained from five papers [23-27], the authors and publication dates of which are listed in Table 8. In total, 16 RSPs were tested for their vertical bearing capacity, and the rock-socketed conditions and ultimate side resistance tests of rock-socketed sections are given in Table 9 (group 0 contains the test results from the present study). From Table 9, in Figure 5, the curve of the coefficient of the 
TABLE 8: Authors and years for references in the present study [23-27].

\begin{tabular}{lcr}
\hline Number & Author(s) & Year \\
\hline 1 & Osterberg & 2001 \\
2 & Gunnink and Kiehne & 2002 \\
3 & Bullock & 2003 \\
4 & McVay et al. & 2003 \\
5 & Nam & 2004 \\
\hline
\end{tabular}

TABle 9: Data from load tests of end-bearing capacities of piles socketed into rock.

\begin{tabular}{lcccc}
\hline Group & $\begin{array}{c}\text { Diameter } d \\
(\mathrm{~mm})\end{array}$ & $\begin{array}{c}\text { Uniaxial compressive strength of rock } \sigma_{c} \\
(\mathrm{MPa})\end{array}$ & $\begin{array}{c}\text { Ultimate resistance of RSP } q_{p} \\
(\mathrm{MPa})\end{array}$ & $\begin{array}{c}\text { Limit coefficient of resistance of } \\
\text { RSP }\end{array}$ \\
\hline 0.1 & 800 & 0.51 & 1.735 & 3.402 \\
0.2 & 800 & 0.51 & 1.448 & 2.839 \\
0.3 & 800 & 0.51 & 1.294 & 2.537 \\
1.1 & - & 120.00 & 12.162 & 0.101 \\
1.2 & - & 120.00 & 35.421 & 0.295 \\
1.3 & - & 84.10 & 69.426 & 0.826 \\
2.1 & 460 & 60.70 & 21.400 & 0.353 \\
2.2 & 460 & 60.70 & 9.100 & 0.150 \\
2.3 & 460 & 60.70 & 22.900 & 0.377 \\
3.1 & 1585 & 1.50 & 6.280 & 4.187 \\
3.2 & 1940 & 3.80 & 6.220 & 1.637 \\
3.3 & 1880 & 0.92 & 3.570 & 3.880 \\
4.1 & 1500 & 2.80 & 8.810 & 3.146 \\
4.2 & 1800 & 2.80 & 6.703 & 2.394 \\
4.3 & 2100 & 2.80 & 5.746 & 2.052 \\
4.4 & 2100 & 2.80 & 6.224 & 2.223 \\
4.5 & 1800 & 2.80 & 3.830 & 1.368 \\
4.6 & 1500 & 2.80 & 4.213 & 1.505 \\
5.1 & 762 & 10.90 & 10.500 & 0.963 \\
\hline
\end{tabular}

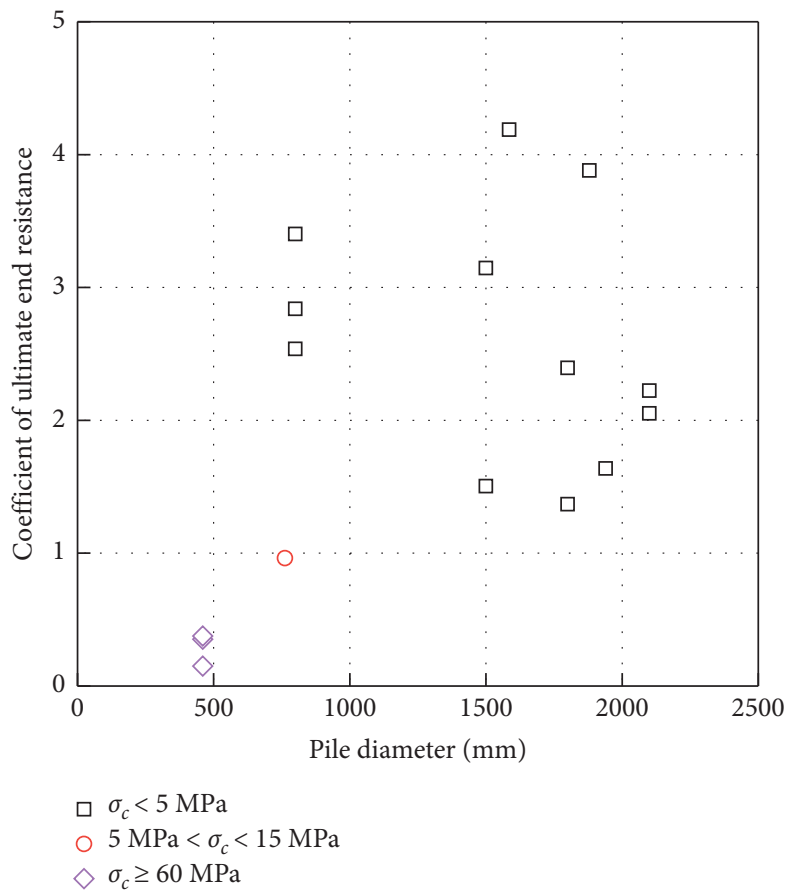

FIGURE 8: Relationship between pile diameter and coefficient of ultimate end resistance. ultimate resistance of an RSP changing with pile diameter is drawn.

Figure 8 shows that the coefficient of ultimate end resistance generally increases with the pile diameter. This trend is more significant when the pile diameter exceeds $1000 \mathrm{~mm}$ and not obvious when the pile diameter is less than $1000 \mathrm{~mm}$. This is mainly because increasing the pile diameter increases the pile end area and resistance when the rock layer at pile end is constant. Meanwhile, the uniaxial compressive strength of the limestone rock layer is almost the same, so the coefficient of ultimate resistance tends to increase with the increase in pile diameter.

\section{Conclusions}

The pile end-bearing layer selected in this project was strongly weathered limestone, and the vertical static load test of a single pile and the stress test of the pile body were carried out simultaneously. In this paper, the pile side and end resistances were studied in depth, and the results showed the following:

(1) During the static load test, the Q-s curve of each of the three test piles exhibited a steep drop, and the settlement under the maximum load of the pile top exceeded $40 \mathrm{~mm}$ in each case. The pile compression 
length reached 1.2 times the pile diameter, and the bearing capacity of a single pile did not meet the design requirements. This suggests that strongly weathered limestone should be avoided as the RSP bearing layer in future projects.

(2) Under each specific load series, the axial force decreased gradually along the pile under test, and the distribution slope decreased gradually, reflecting the characteristics of pile side resistance gradually playing from top to end along the pile body. As the pile load was increased, the rate of increase in the pile end resistance increased gradually. The pile end resistance increased linearly with the increase in pile pressure.

(3) Under the action of the ultimate load, the pile side resistance reached its maximum value in the strongly weathered limestone strata, while the side resistance due to the miscellaneous fill and silty clay strata was higher than the recommended value in the specification, but the side resistance due to the strongly weathered limestone strata was lower than the recommended value. Compared with existing literature, it is found that there was no significant correlation between the coefficient of rock-induced ultimate side resistance and the pile diameter in the rock-socketed segment.

(4) Under the action of the ultimate load, the pile end resistance of test piles TP1-TP3 accounted for 53.8\%, $42.4 \%$, and $38.4 \%$, respectively, of the pile top load. At its highest, the ratio of the pile end resistance to the upper load exceeded 50\%, far higher than that under normal working conditions. Compared with existing literature, it is found that the resistance of the pile end has been brought into full play and shows the characteristics of an end-bearing pile. Overall, the coefficient of ultimate resistance increased with the pile diameter, but that increase was more significant when the pile diameter exceeded $1000 \mathrm{~mm}$.

\section{Data Availability}

The experimental data used to support the findings of this study will be made available upon request.

\section{Conflicts of Interest}

The authors declare that there are no conflicts of interest regarding the publication of this paper.

\section{Acknowledgments}

This work was supported by the National Natural Science Foundation of China (51708316 and 51778312), China Postdoctoral Science Foundation Funding (2018M632641), Shandong Key Research and Development Program (2017GSF16107 and 2018GSF11700), Shandong Provincial Postdoctoral Innovation Program of China (201903043), Higher Educational Science and Technology Program of
Shandong Province (J16LG02), and Qingdao Postdoctoral Applied Research Program (2018101).

\section{References}

[1] P. J. N. Pells and R. M. Turner, "Elastic solutions for the design and analysis of rock-socketed piles," Canadian Geotechnical Journal, vol. 16, no. 3, pp. 481-487, 1979.

[2] J. Zhang, D. Wu, and H. Du, "Experimental study on bearing behavior and failure mode of rock-socketed piles," Chinese Journal of Rock Mechanics and Engineering, vol. 23, no. 2, pp. 320-323, 2004.

[3] N. F. Ismael and H. A. Al-Sanad, "Uplift capacity of bored piles in calcareous soils," Journal of Geotechnical Engineering, vol. 112, no. 10, pp. 928-940, 1986.

[4] M. H. Zhao, Y. Lei, and X. M. Liu, "Load transfer analysis of rock-socketed piles based on pile-rock structural surface characteristics," Chinese Journal of Rock Mechanics and Engineering, vol. 28, no. 1, pp. 103-110, 2009.

[5] C. F. Leung and H.-Y. Ko, "Centrifuge model study of piles socketed in soft rock," Soils and Foundations, vol. 33, no. 3, pp. 80-91, 1993.

[6] C. E. Ho, "Base grouted bored pile on weak granite," in Proceedings of the Third International Conference on Grouting and Ground Treatment, p. 1, New Orleans, LA, USA, 2003.

[7] I. B. Donald, H. K. Chiu, and S. W. Sloan, "Theoretical analyses of rock socketed piles," in Proceedings of the International Conference on Structural Foundations on Rock, p. 1, Sydney, Australia, May 1980.

[8] H. Xing, J. Wu, and Y. Luo, "Field tests of large-diameter rocksocketed bored piles based on the self-balanced method and their resulting load bearing characteristics," European Journal of Environmental and Civil Engineering, vol. 23, no. 12, pp. 1535-1549, 2019.

[9] L. Tosini, A. Cividini, and G. Gioda, "A numerical interpretation of load tests on bored piles," Computers and Geotechnics, vol. 37, no. 3, pp. 425-430, 2010.

[10] X.-y. Chen, M.-y. Zhang, and X.-y. Bai, "Axial resistance of bored piles socketed into soft rock," KSCE Journal of Civil Engineering, vol. 23, no. 1, pp. 46-55, 2019.

[11] X. L. Lu, Z. Z. Qian, W. Z. Yang et al., "Limital drag coefficient of rock in rock-socketed section of rock-socketed pile," Civil Engineering and Environmental Engineering, vol. 40, no. 6, pp. 29-38, 2018.

[12] X. L. Lu, Z. Z. Qian, W. Z. Yang et al., "Development characteristics of ultimate end resistance of rock-socketed pile and its end resistance coefficient," Chinese and English Journal of Civil and Environmental Engineering, vol. 41, no. 4, pp. 26-35, 2019.

[13] People's Republic of China Industry Standards Writing Group, Technical Specifications for Building Pile Testing: JGJ 106-2014, China Building Industry Press, Beijing, China, 2014.

[14] Y. C. Kog, "Integrity problem of large-diameter bored piles," Journal of Geotechnical and Geoenvironmental Engineering, vol. 135, no. 2, pp. 237-245, 2009.

[15] R. Delpak, J. R. Omer, and R. B. Robinson, "Load/settlement prediction for large-diameter bored piles in Mercia mudstone," Proceedings of the Institution of Civil Engineers Geotechnical Engineering, vol. 143, no. 4, pp. 201-224, 2000.

[16] C. W. W. Ng, T. L. Y. Yau, J. H. M. Li, and W. H. Tang, "New failure load criterion for large diameter bored piles in weathered geomaterials," Journal of Geotechnical and Geoenvironmental Engineering, vol. 127, no. 6, pp. 488-498, 2001. 
[17] M. C. McVay, F. C. Townsend, and R. C. Williams, "Design of socketed drilled shafts in limestone," Journal of Geotechnical Engineering, vol. 118, no. 10, pp. 1626-1637, 1992.

[18] B. Gunnink and C. Kiehne, "Pile bearing in Burlington limestone," in Proceedings of the Transportation Conference, pp. 145-148, Newport Beach, CA, USA, April 1998.

[19] M. Long, "Skin friction for piles socketed in hard rock," in Proceedings of the International Conference on Geotechnical and Geological Engineering (GeoEng 2000), Melbourne, Australia, November 2000.

[20] R. J. Castelli and K. Fan, "O-cell test results for drilled shafts in marl and limestone," in Proceedings of the International Deep Foundations Congress, pp. 807-823, Orlando, FL, USA, February 2002.

[21] A. F. Williams and P. J. N. Pells, "Side resistance rock sockets in sandstone, mudstone, and shale," Canadian Geotechnical Journal, vol. 18, no. 4, pp. 502-513, 1981.

[22] H. G. Poulos, "Piled raft foundations: design and applications," Géotechnique, vol. 51, no. 2, pp. 95-113, 2001.

[23] J. Osterberg, "Load testing high capacity piles: what have we learned," in Proceedings of the 5th International Conference on Deep Foundation Practice, Singapore, 2001.

[24] B. Gunnink and C. Kiehne, "Capacity of drilled shafts in burlington limestone," Journal of Geotechnical and Geoenvironmental Engineering, vol. 128, no. 1, pp. 539-545, 2002.

[25] P. J. Bullock, "A study of the setup behavior of drilled shafts," Report submitted to the Florida Department of Transportation, University of Florida, Gainesville, FL, USA, 2003.

[26] M. McVay, M. Ellisk, J. Villegas et al., "Static and dynamic field testing of drilled shafts: suggested guidelines on their use and for FDOT structures," Report WPI No.BC354-08, FDOT, Department of Civil and Costal Engineering, University of Florida, Gainesville, FL, USA, 2003.

[27] M. S. Nam, Improved Design for Drilled Shafts in Rock, University of Houston, Houston, TX, USA, 2004. 